\title{
CrystEngComm
}

Cite this: CrystEngComm, 2014, 16 3613

Received 21st December 2013, Accepted 17th February 2014

DOI: $10.1039 / c 3 c e 42601 \mathrm{~g}$

www.rsc.org/crystengcomm

\section{Reactivity of the drug methimazole and its iodine adduct with elemental zinc $\dagger$}

\author{
Francesco Isaia, ${ }^{* a}$ M. Carla Aragoni, ${ }^{a}$ Massimiliano Arca, ${ }^{a}$ Claudia Caltagirone, ${ }^{a}$ \\ Alessandra Garau, ${ }^{a}$ Peter G. Jones, ${ }^{b}$ Vito Lippolis ${ }^{a}$ and Riccardo Montis ${ }^{a}$
}

\begin{abstract}
The reactivity of zinc complexes with $\mathrm{N}, \mathrm{S}$-donor molecules may be of relevance to the study of $\mathrm{Zn}$-metalloproteins and -metalloenzymes. In this context, the zinc complex $\left[\mathrm{Zn}(\mathrm{MelmSH})_{2} \mathrm{I}_{2}\right]$ was synthesised by the reaction of zinc powder with the 1:1 iodine adduct of the drug methimazole $\left[(\mathrm{MelmSH}) \cdot \mathrm{I}_{2}\right]$. The molecular structure of the complex, elucidated by $\mathrm{X}$-ray diffraction analysis, showed a tetrahedral zinc(II) centre coordinated by two neutral methimazole units (through the sulfur atoms) and two iodides. From the reaction of MelmSH and $\mathrm{Zn}$ powder, the complex [ $\left.\mathrm{Zn}(\mathrm{MelmSH})(\mathrm{MelmS})_{2}\right](\mathrm{MelmS}=$ deprotonated form of methimazole) was separated and characterised. An analysis of the crystal packing of the neutral complexes [ $\left.\mathrm{Zn}(\mathrm{MelmSH})_{2} \mathrm{X}_{2}\right](\mathrm{X}=\mathrm{l}, \mathrm{Br}$ and $\mathrm{Cl})$ and the ionic complex [ $\left.\mathrm{Zn}(\mathrm{MelmSH})_{3}\right]$ ] showed that in all of the complexes the sulfur atom, in addition to binding to the metal centre, contributes to the formation of 1-D chains built via $\mathrm{C}(4)-\mathrm{H} \cdots \mathrm{S}$ and $\mathrm{N}-\mathrm{H} \cdots \mathrm{X}$ interactions in the neutral complexes, and via $\mathrm{C}(4)-\mathrm{H} \cdots \mathrm{S}$ and $\mathrm{N}-\mathrm{CH}_{3} \cdots \mathrm{S}$ interactions in the ionic complex [Zn(MelmSH) 3 I]I. The deprotonation/protonation of the coordinated methimazole units can modulate the coordination environment at the $\mathrm{Zn}$ core. From the reaction of complex $\left[\mathrm{Zn}(\mathrm{MelmSH})_{3} \mid\right] \mid$ with a strong non-coordinating organic base, we have shown that, as a consequence of the $\mathrm{NH}$ deprotonation of methimazole S-coordinated to zinc(II), the ligand coordination mode changes from S-monodentate to N,S-bridging. Correspondingly, in the complex [ $\left.\mathrm{Zn}(\mathrm{MelmSH})(\mathrm{MelmS})_{2}\right]$, the MelmS that displays the N,S-bridging mode at zinc can be N-protonated and thereby changes to the S-monodentate coordination.
\end{abstract}

\section{Introduction}

Iodine adducts of S-donor containing ligands $\left(\mathrm{DS} \cdot \mathrm{I}_{2}\right)$ have recently been employed as oxidizing agents towards elemental metals $\left(\mathbf{M}^{0}\right),{ }^{1 a}$ whereby the one-step reaction (1) proceeds in non-aqueous solvents under mild reaction conditions. This reaction is currently being exploited for the recovery of precious and/or toxic metals from industrial waste. ${ }^{2}$ Another interesting aspect of this oxidation concerns the possibility of synthesizing transition- and main-group metal complexes with DS ligands, as these complexes are often not obtainable by conventional synthetic procedures. A great number of $I_{2}$ adducts of thioamide-containing molecules have been synthesized to date. ${ }^{1 b}$ Though all of them can potentially be considered good candidates as oxidising reagents, only a few of

\footnotetext{
${ }^{a}$ Dipartimento di Scienze Chimiche e Geologiche, Università degli Studi di Cagliari, Cittadella Universitaria, 09042 Monserrato (CA), Italy. E-mail: isaia@unica.it; Fax: +39 070 6754456; Tel: +39070 6754496

${ }^{b}$ Institut für Anorganische und Analytische Chemie, Technische Universität Braunschweig, Hagenring 30, 38106 Braunschweig, Germany

$\dagger$ Electronic supplementary information (ESI) available: Electrospray Ionization Mass Spectroscopy (ESI-MS) data. CCDC 976347. For ESI and crystallographic data in CIF or other electronic format see DOI: 10.1039/c3ce42601g
}

them were successful in the oxidative dissolution of metals as summarised in Table 1.

$$
\mathrm{DS} \cdot \mathrm{I}_{2}+\mathrm{M}^{0} \underset{\mathrm{Et}_{2} \mathrm{O} \text { or } \mathrm{CH}_{2} \mathrm{CL}_{2}}{1-14 \text { days } / \text { r.t. }} \text { oxidized/complexed metal }
$$

Table 1 Structurally characterised metal complexes obtained by using $\mathrm{I}_{2}$-adducts of thioamide-containing molecules as oxidizing reagents towards metal powders and mercury(1)

\begin{tabular}{|c|c|c|c|c|}
\hline Adduct $^{a}$ & Metal & Solvent & Main product/s & Ref. \\
\hline $\mathrm{MeImSH} \cdot \mathrm{I}_{2}$ & $\mathrm{Hg}$ & $\mathrm{CH}_{2} \mathrm{Cl}_{2}$ & {$\left[\mathrm{Hg}_{2} \mathrm{I}_{4}(\mathrm{MeImSH})_{2}\right]$} & $2 a$ \\
\hline $\mathrm{PTU} \cdot \mathrm{I}_{2}$ & $\mathrm{Hg}$ & $\mathrm{CH}_{2} \mathrm{Cl}_{2}$ & {$\left[\mathrm{Hg}(\mathrm{PTU})_{2} \mathrm{I}_{2} \cdot \mathrm{HgI}_{2}\right]$} & $2 a$ \\
\hline $\mathrm{mbtt} \cdot \mathrm{I}_{2}$ & $\mathrm{Au}$ & $\mathrm{Et}_{2} \mathrm{O}$ & {$\left[\mathrm{Au}(\mathrm{mbtt})_{2}\right] \mathrm{I}_{3}$} & $2 b$ \\
\hline $\mathrm{mbit} \cdot \mathrm{I}_{2}$ & $\mathrm{Au}$ & $\mathrm{Et}_{2} \mathrm{O}$ & $(\mathrm{mtbiH})_{2}\left[\mathrm{AuI}_{4}\right]_{3}{ }^{b}$ & $2 b$ \\
\hline $\mathrm{bmitm} \cdot 2 \mathrm{I}_{2}$ & Sn & $\mathrm{Et}_{2} \mathrm{O}$ & {$\left[\mathrm{Sn}(\mathrm{bmitm})_{2} \mathrm{I}_{2}\right]\left(\mathrm{I}_{3}\right)_{2} \cdot 2 / 3 \mathrm{I}_{2}$} & $2 c$ \\
\hline $\mathrm{Me}_{2}$ dazdt $\cdot 2 \mathrm{I}_{2}$ & $\mathrm{Au}$ & THF & {$\left[\mathrm{Au}\left(\mathrm{Me}_{2} \mathrm{dazdt}\right) \mathrm{I}_{2}\right] \mathrm{I}_{3}$} & $2 d$ \\
\hline $\mathrm{Me}_{2}$ dazdt $\cdot 2 \mathrm{I}_{2}$ & $\mathrm{Hg}$ & THF & {$\left[\mathrm{Hg}\left(\mathrm{Me}_{2} \mathrm{dazdt}\right) \mathrm{I}_{2}\right]$} & $2 e$ \\
\hline $\mathrm{Me}_{2}$ dazdt $\cdot 2 \mathrm{I}_{2}$ & Pd & THF & {$\left[\mathrm{Pd}\left(\mathrm{Me}_{2} \mathrm{dazdt}\right)_{2}\right]\left(\mathrm{I}_{3}\right)_{2}$} & $2 f$ \\
\hline
\end{tabular}

${ }^{a}$ MeImSH $=$ methimazole, 1 -methyl-3H-imidazole-2-thione, PTU $=$ propylthiouracil, 6-propyl-2-sulfanylpyrimidin-4-one, $\mathrm{mbtt}=3$-methylbenzothiazole-2-thione, mbit $=1$-methyl-1 $H$-benzimidazole- $2(3 H)$ thione, bmitm $=1,1^{\prime}$-bis(3-methyl-4-imidazoline-2-thione)methane, $\mathrm{Me}_{2}$ dazdt $=N, N^{\prime}$-dimethylperhydro-1,4-diazepine-2,3-dithione. ${ }^{b} \mathrm{mtbiH}=2$-methylthiobenzimidazolium cation. 
The dual role played by the S-donors (DS) in the reaction (1) has recently been recognised. ${ }^{2 a, b}$ In addition to polarising the bound $I_{2}$ molecule, DS acts as a good coordinating agent towards the oxidised metal ion. In previous studies, we have identified some factors that influence the course of the reaction (1). First, the DS $I_{2}$ adduct should be inherently stable to avoid the oxidation of the donor and the formation of (poly)iodides, or iodine(I) derivatives (Scheme 1), since under these circumstances, the oxidation/complexation of metals is not observed. Moreover, if the adduct DS $\mathrm{I}_{2}$ tends to dissociate, either the equilibrium species DS or $\mathrm{I}_{2}$ can react with the oxidized/complexed metal, with the result that the outcome of reaction (1) becomes very unpredictable. The second important factor concerns the nature of the metal. Even if the oxidation of metals whose ions are "hard" often occurs under the experimental conditions outlined in reaction (1), the corresponding complexes with the ligand DS are difficult to isolate since the "soft" S-donor atom is intrinsically a poor coordinating agent towards these ions, and the formation of non-crystallizable oils is commonly observed. Thirdly, both the reaction conditions (solvent and temperature) and the DS $\mathrm{I}_{2}$ to $\mathrm{M}^{0}$ molar ratio influence the outcome of the reaction and need to be optimised in order to favour the formation of solid compounds.

Among the thioamide derivatives, the antithyroid drug methimazole $^{4 b}$ (1-methyl-3H-imidazole-2-thione) (MeImSH), as shown in Fig. 1, is of interest because it forms the very stable adduct $(\mathrm{MeImSH}) \cdot \mathrm{I}_{2}$ both in solution and in the solid state. ${ }^{4 b, c}$ The large formation constant $\left(K_{\mathrm{f}}\right.$ of $92433 \mathrm{M}^{-1}$ in $\mathrm{CH}_{2} \mathrm{Cl}_{2}$ at $\left.25{ }^{\circ} \mathrm{C}\right)^{4 b}$ ensures that the $(\mathrm{MeImSH}) \cdot \mathrm{I}_{2}$ adduct is the only "active" oxidant species in reaction (1). This adduct proved to be capable of dissolving and complexing liquid mercury in $\mathrm{CH}_{2} \mathrm{Cl}_{2}$, leading to good yield of the neutral complex $\left[\mathrm{Hg}_{2} \mathrm{I}_{4}(\mathrm{MeImSH})_{2}\right]^{2 a}$ In light of these good results, we have turned our attention to the lightest element of group 12. Zinc is one of the essential chemical elements for living organisms, and the presence of this element in a very low concentration $^{5 a}$ is fundamental in catalytic, structural, and regulatory living processes. $^{5 b}$ Since the discovery in 1939 that the enzyme carbonic anhydrase contains stoichiometric amounts of zinc, ${ }^{5 c}$ more than 3000 zinc proteins have been identified. $^{5 d, e}$ With so many proteins requiring zinc, the

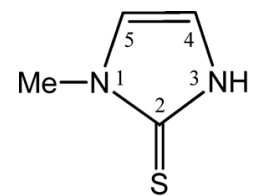

MelmSH

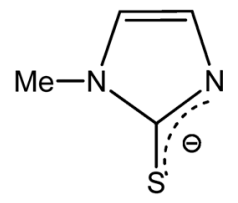

Melms

Fig. 1 Chemical structures of methimazole (MelmSH) and its anion (MelmS).

concentration range in which $\mathrm{Zn}$ (II) ions are maintained at specific cellular concentrations to exert cellular regulation, transport, and homeostasis is the result of many processes, most of which have yet to be clarified. ${ }^{5 f}$ For these reasons, the exposure to chemicals, or the therapeutic consumption of metal chelating agents that interfere with zinc buffering can either result in zinc deficiency, and/or in the potential reduction of drugs efficacy. ${ }^{6}$ Methimazole, which is widely used for the long-term treatment of hyperthyroidism and Graves' disease, can potentially interact/interfere with the zinc-buffering system and Zn-metalloenzyme activities. ${ }^{4 b, 6 a}$ Experimental evidence on this point has been reported by Ferrer et al. ${ }^{6 b}$ who determined for methimazole a moderate inhibitor effect on alkaline phosphatase activity $\left(\mathrm{IC}_{50}=70 \mu \mathrm{M}\right)$.

Investigation of the coordination chemistry of zinc with methimazole can therefore provide useful indications of the coordination number, the geometry at the metal centre, and the elements involved, since methimazole can behave either as a neutral or an anionic ligand ${ }^{7}$ (Fig. 1) and can coordinate through the sulfur and/or the nitrogen atoms. Moreover, the characterization of zinc complexes with $\mathrm{N}, \mathrm{S}$-donor molecules provides information for modelling the binding between the zinc metal ion and $\mathrm{N}$ - and $\mathrm{S}$ - donor sites and thus predicting the structure of Zn-metalloproteins and -metalloenzymes. We report here the reactivity of adduct $(\mathrm{MeImSH}) \cdot \mathrm{I}_{2}$ in dichloromethane with zinc powder and the characterisation, also by means of X-ray diffraction, of the isolated neutral zinc(II) complex $\left[\mathrm{Zn}(\mathrm{MeImSH})_{2} \mathrm{I}_{2}\right]$. The S-coordination of $\mathrm{MeImSH}$ to the $\mathrm{ZnX}_{2}$ moiety and also the crystal packing in complexes $\left[\mathrm{Zn}(\mathrm{MeImSH})_{2} \mathrm{X}_{2}\right][\mathrm{X}=\mathrm{I}, \mathrm{Br}$, and $\mathrm{Cl}]$ and $\left[\mathrm{Zn}(\mathrm{MeImSH})_{3} \mathrm{I}\right] \mathrm{I}$ have been compared to identify the nature of the intermolecular interactions. The reactivity of MeImSH towards zinc powder and the characterisation of the resulting complex

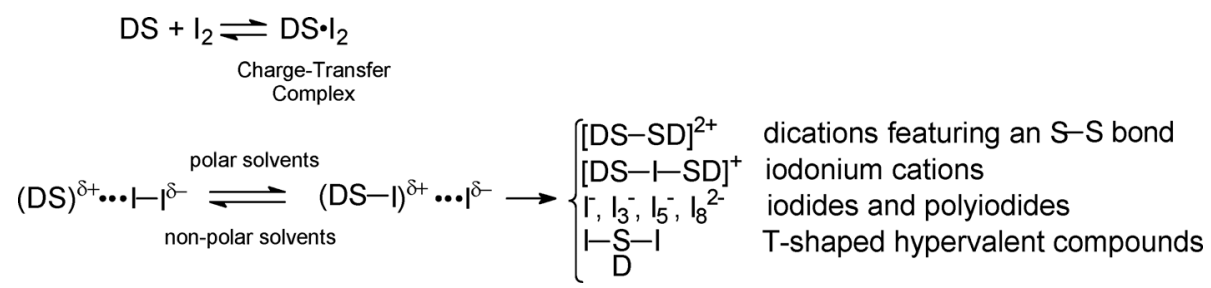

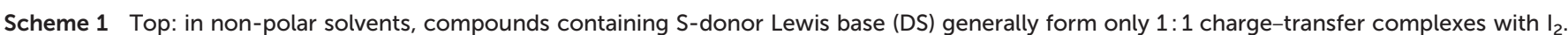

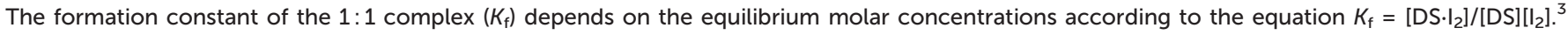

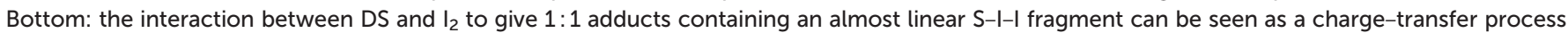

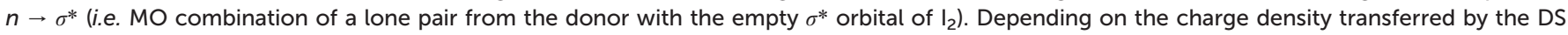

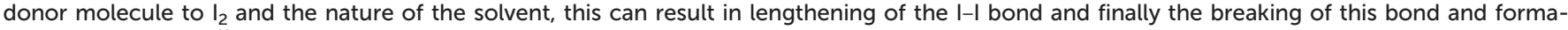
tion of new species. ${ }^{1 b}$ 
$\left[\mathrm{Zn}(\mathrm{MeImSH})(\mathrm{MeImS})_{2}\right]$ are also reported. Moreover, the coordinating mode of methimazole in zinc complexes with respect to its neutral (thione) or anionic (thionate) form is discussed.

\section{Results and discussion}

\section{Reactivity of the adduct (MeImSH) $\mathbf{I}_{2}$ with $\mathrm{Zn}$ powder}

The reaction between the adduct $(\mathrm{MeImSH}) \cdot \mathrm{I}_{2}$ and elemental zinc powder $\left(\mathrm{CH}_{2} \mathrm{Cl}_{2}, 25{ }^{\circ} \mathrm{C}\right)$ in 1:1 and 2:1 molar ratios was carried out for two days. During this time the zinc dissolves completely and the dark red colour of the mixture due to the CT-complex (MeImSH) $\mathrm{I}_{2}$ turned to pale red; no separation of solid products was observed. Evaporation of the solution in air resulted in dark red sticky oily products that we failed to crystallize. To overcome this point, the same reaction was also carried out, but increasing the amount of MeImSH to obtain a molar ratio $\mathrm{MeImSH}:(\mathrm{MeImSH}) \cdot \mathrm{I}_{2}: \mathrm{Zn}$ of $1: 1: 1$; under these reaction conditions the solution gradually turned from dark red to pale yellow within $48 \mathrm{~h}$, thereafter affording the pale yellow crystalline zinc(II) complex of stoichiometry $\left[\mathrm{Zn}(\mathrm{MeImSH})_{2} \mathbf{I}_{2}\right]$ by slow evaporation in air. It is noteworthy that Fujisawa et al. ${ }^{8}$ were not able to synthesise this complex by reacting $\mathrm{ZnI}_{2}$ with $\mathrm{MeImSH}$ in $\mathrm{MeOH}$, the unexpected ionic complex of stoichiometry $\left[\mathrm{Zn}(\mathrm{MeImSH})_{3} \mathrm{I}\right] \mathrm{I}$ was instead obtained. We also tested whether the complex $\left[\mathrm{Zn}(\mathrm{MeImSH})_{2} \mathrm{I}_{2}\right]$ could be obtained from the reaction of $\mathrm{ZnI}_{2}$ with $\mathrm{MeImSH}$ (1:2 molar ratio) in $\mathrm{CH}_{2} \mathrm{Cl}_{2}$, but we again obtained the complex $\left[\mathrm{Zn}(\mathrm{MeImSH})_{3} \mathrm{I}\right] \mathrm{I}$.

The experimental data show that the adduct (MeImSH) $\cdot \mathrm{I}_{2}$ in $\mathrm{CH}_{2} \mathrm{Cl}_{2}$ can successfully oxidize zinc powder to $\mathrm{Zn}$ (II) by a twoelectron transfer process according to the overall reaction (2).

$$
(\mathrm{MeImSH}) \cdot \mathrm{I}_{2}+\mathrm{MeImSH}+\mathrm{Zn} \rightarrow \mathrm{Zn}(\mathrm{MeImSH})_{2} \mathrm{I}_{2}
$$

This reaction represents a forward step with respect to reaction (1), as it has allowed us to improve the oxidativedissolution process avoiding the formation of oily products arising from an incorrect molar ratio of the reagents. In previous studies, we recognised that the oxidising and complexing properties of DS $\mathrm{I}_{2}$ adducts towards zero-valent metals could be interpreted considering the charge separation along the $\mathrm{S}-\mathrm{I}_{b}-\mathrm{I}_{t}$ moiety induced by the $S \rightarrow I_{2}$ interaction to form the reactive polarized $[\mathrm{DS}-\mathrm{I}]^{\delta+} \cdots \mathrm{I}^{\delta-}$ system. In the case of the adduct $(\mathrm{MeImSH}) \cdot \mathrm{I}_{2}$, the calculated NBO charge distribution ${ }^{2 a}$ showed a sulfur atom which is slightly positive $(0.078 \mathrm{e})$ and a permanent charge separation between the iodine atoms of $0.348 \mathrm{e}$ (NBO charges: -0.367 and -0.19 e for $\mathrm{I}_{t}$ and $\mathrm{I}_{b}$, respectively), with a consequent increase of the reactivity with respect to that of molecular iodine. ${ }^{9}$ As similarly proposed for the oxidation of liquid mercury to yield the neutral mercury(II) complex $\left[\mathrm{Hg}_{2}(\mathrm{MeImSH})_{2} \mathrm{I}_{4}\right],{ }^{2 a}$ it is reasonable to hypothesise that the oxidation/complexation of zinc proceeds via a mechanism of oxidative addition ${ }^{10}$ with the (MeImSH-I) ${ }^{\delta+}$ moiety acting as an electrophilic agent. Based on the stoichiometry of the isolated complex $\left[\mathrm{Zn}(\mathrm{MeImSH})_{2} \mathrm{I}_{2}\right]$, a second unit of $\mathrm{MeImSH}$ binding to the zinc(II) center provides a stable tetrahedral coordination geometry.
Table 2 Crystallographic data and structure refinement details

\begin{tabular}{ll}
\hline Compound & {$\left[\mathrm{Zn}(\mathrm{MeImSH})_{2} \mathrm{I}_{2}\right]$} \\
\hline Formula & $\mathrm{C}_{8} \mathrm{H}_{12} \mathrm{I}_{2} \mathrm{~N}_{4} \mathrm{~S}_{2} \mathrm{Zn}$ \\
$\mathrm{M} . \mathrm{W}$. & 547.51 \\
Crystal system & Monoclinic \\
Space group & $P 2_{1} / n$ \\
$a / \AA$ & $10.7697(11)$ \\
$b / \AA$ & $10.1580(8)$ \\
$c / \AA$ & $29.054(3)$ \\
$\alpha /{ }^{\circ}$ & 90.00 \\
$\beta /{ }^{\circ}$ & $91.111(4)$ \\
$\gamma / \circ$ & 90.00 \\
$V / \AA$ & $3177.8(5)$ \\
$T / K$ & $133(2)$ \\
Crystal shape & Tablet \\
Colour & Pale yellow \\
$Z$ & 8 \\
All reflns & 64301 \\
Un. reflns & 9699 \\
$R_{\text {int }}$ & 0.0275 \\
$R_{1, \text { obs }}[I>2 \sigma(I)]$ & 0.0181 \\
$R_{1, \text { all }}$ & 0.0234 \\
$w R_{2}($ obs $)$ & 0.0395 \\
$w R_{2}($ all $)$ & 0.0412 \\
&
\end{tabular}

\section{Crystal structure of the complex $\left[\mathrm{Zn}(\mathrm{MeImSH})_{2} \mathrm{I}_{2}\right]$}

The complex $\left[\mathrm{Zn}(\mathrm{MeImSH})_{2} \mathrm{I}_{2}\right]$ crystallises in a monoclinic crystal system (space group $P 2_{1} / n$ ). A summary of the crystal data is reported in Table 2 .

The asymmetric unit of $\left[\mathrm{Zn}(\mathrm{MeImSH})_{2} \mathrm{I}_{2}\right]$ (Fig. 2) consists of two independent molecules (1 and 2), each featuring a $\mathrm{Zn}^{2+}$ cation adopting a slightly distorted tetrahedral geometry with two MeImSH units, coordinating via sulfur atoms $\mathrm{S}(1)$ and $\mathrm{S}(2)$ or S(3) and S(4), respectively, and by two $\mathrm{I}^{-}$anions, coordinating via iodides $\mathrm{I}(1)$ and $\mathrm{I}(2)$ or $\mathrm{I}(3)$ and $\mathrm{I}(4)$, respectively. Selected bond distances and angles for units 1 and 2 are presented in Table 3 . The molecules differ slightly in ring orientations; a least-squares fit of all non-H atoms gave an r.m.s. deviation of $0.18 \AA$ A. For the sake of completeness, we have also included the data concerning the structures previously published $\left[\mathrm{Zn}(\mathrm{MeImSH})_{2} \mathrm{Br}_{2}\right],{ }^{8}\left[\mathrm{Zn}\left(\mathrm{MeImSH}_{2} \mathrm{Cl}_{2}\right],{ }^{8}\right.$ and

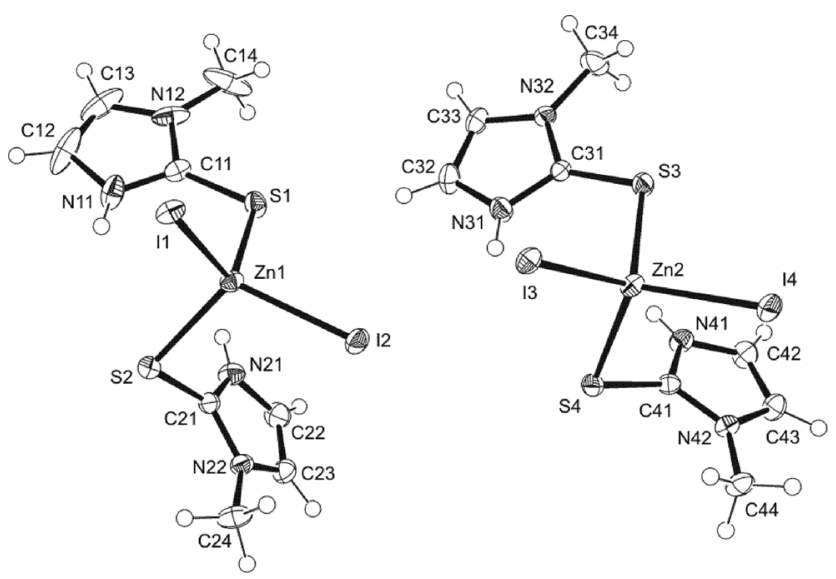

Fig. 2 The two independent molecules 1 (left) and 2 (right) that constitute the asymmetric unit of complex $\left[\mathrm{Zn}(\mathrm{MelmSH})_{2} \mathrm{I}_{2}\right]$. 
Table 3 Selected bond distances $(\AA)$ and angles $\left({ }^{\circ}\right)$ for the two independent units 1 and 2 of complex $\left[\mathrm{Zn}(\mathrm{MelmSH})_{2} \mathrm{I}_{2}\right]$, and complexes $\left[\mathrm{Zn}(\mathrm{MelmSH})_{2} \mathrm{Br}_{2}\right]$ (ref. 8), $\left[\mathrm{Zn}(\mathrm{MelmSH})_{2} \mathrm{Cl}_{2}\right]$ (ref. 8), and $\left[\mathrm{Zn}(\mathrm{MelmSH})_{3} \mathrm{III}\right.$ (ref. 8)

\begin{tabular}{llllll}
\hline & 1 & 2 & {$\left[\mathrm{Zn}(\mathrm{MeImSH})_{2} \mathrm{Br}_{2}\right]$} & {$\left[\mathrm{Zn}(\mathrm{MeImSH})_{2} \mathrm{Cl}_{2}\right]$} & {$\left[\mathrm{Zn}(\mathrm{MeImSH})_{3} \mathrm{I}\right] \mathrm{I}$} \\
\hline $\mathrm{Zn}-\mathrm{S} 1$ & $2.3392(5)$ & $2.3562(5)$ & $2.338(2)$ & $2.336(2)$ & $2.376(3)$ \\
$\mathrm{Zn}-\mathrm{S} 2$ & $2.3703(5)$ & $2.3669(5)$ & $2.342(2)$ & $2.345(1)$ & $2.375(3)$ \\
$\mathrm{Zn}-\mathrm{X} 1$ & $2.6011(3)$ & $2.5807(3)$ & $2.390(1)$ & $2.259(1)$ & $2.574(2)$ \\
$\mathrm{Zn}-\mathrm{X} 2$ & $2.5864(3)$ & $2.5824(3)$ & $2.390(1)$ & $1.709(4)$ & $1.71(1)$ \\
C1-S1 & $1.706(2)$ & $1.707(2)$ & $1.702(9)$ & $1.714(5)$ & $1.71(1)$ \\
C1-S2 & $1.721(2)$ & $1.722(2)$ & $1.720(7)$ & $110.07(5)$ & $102.54(5)$ \\
X1-Zn-X2 & $117.89(1)$ & $116.58(1)$ & $109.57(4)$ & $115.39(5)$ & - \\
X1-Zn-S1 & $101.48(1)$ & $103.87(1)$ & $118.67(6)$ & $118.19(5)$ & $112.98(8)$ \\
X2-Zn-S1 & $111.57(2)$ & $110.17(2)$ & $106.93(6)$ & $107.00(5)$ & - \\
X1-Zn-S2 & $109.45(1)$ & $110.26(1)$ & $101.28(6)$ & $103.83(5)$ & $105.6(1)$
\end{tabular}

$\left[\mathrm{Zn}(\mathrm{MeImSH})_{3} \mathrm{I}\right] \mathrm{I},{ }^{8}$ CSD-REFCOD: GARPIZ, GARPEV, and GARPOF, respectively.

In particular, we are interested in the comparison of molecules 1-2 with the two isostructural complexes $\left[\mathrm{Zn}(\mathrm{MeImSH})_{2} \mathrm{Br}_{2}\right]$ and $\left[\mathrm{Zn}(\mathrm{MeImSH})_{2} \mathrm{Cl}_{2}\right]$, which only differ in the coordinating halides. However, since it is relevant for the scope of this paper, we also comment on the complex $\left[\mathrm{Zn}(\mathrm{MeImSH})_{3} \mathrm{I}\right] \mathrm{I}$, which features a different structure with three S-monodentate MeImSH units and one iodide tetrahedrally coordinated to the zinc(II), and a second iodide ion acting as the counter-ion. The comparison of the geometrical parameters shows small differences for the $\left[\mathrm{Zn}(\mathrm{MeImSH})_{2} \mathrm{X}_{2}\right]$ complexes ( $\mathrm{X}=\mathrm{I}, \mathrm{Br}$, and $\mathrm{Cl})$. In particular, units 1 and 2 show differences mainly involving the $\mathrm{Zn}-\mathrm{X}$ distances. These increase along the series $\mathrm{Cl}-\mathrm{Br}-\mathrm{I}$. The bond angles are similar and all of the structures adopt a slightly distorted tetrahedral geometry. The $\mathrm{C}-\mathrm{S}$ bond distances are very similar for all of the structures, with values lying in the range 1.70-1.73 $\AA$. However, the analysis of the conformations reveals differences concerning the orientations adopted by the two MeImSH moieties. These are very similar for the $\mathrm{Cl}$ and $\mathrm{Br}$ complexes, in which the conformation is locked via $\mathrm{N}-\mathrm{H} \cdots \mathrm{X}$ intra-molecular interactions $(\mathrm{N}-\mathrm{H} \cdots \mathrm{X}$ distances are $2.47 \AA$ for $\left[\mathrm{Zn}(\mathrm{MeImSH})_{2} \mathrm{Cl}_{2}\right]$ and $2.60 \AA$ for $\left.\left[\mathrm{Zn}(\mathrm{MeImSH})_{2} \mathrm{Br}_{2}\right]\right)$, but differ for the two symmetrically independent units of $\mathbf{1}$ and 2 , in which no intramolecular interactions are observed. This is represented in Fig. 3 in which the units 1 and 2, and the tetrahedral unit of $\left[\mathrm{Zn}(\mathrm{MeImSH})_{2} \mathrm{Cl}_{2}\right]$ (reported as representative of the isostructural set) are shown.

$\left[\mathrm{Zn}(\mathrm{MeImSH})_{2} \mathrm{Cl}_{2}\right]$ and $\left[\mathrm{Zn}(\mathrm{MeImSH})_{2} \mathrm{Br}_{2}\right]$ are compared. In Fig. 3, the tetrahedral unit of $\left[\mathrm{Zn}(\mathrm{MeImSH})_{3} \mathrm{I}\right] \mathrm{I}$ is also reported for completeness.

\section{Packing analysis}

The units 1 and 2 are alternately connected to each other via weak $\mathrm{C}-\mathrm{H} \cdots \mathrm{S}$ interactions $(\mathrm{C}-\mathrm{H} \cdots \mathrm{S}$ distances are 2.86 and $2.73 \AA$ A) assisted by $\mathrm{N}-\mathrm{H} \cdots \mathrm{I}$ contacts $[\mathrm{N}-\mathrm{H} \cdots \mathrm{I}$ distances are 3.20(3) and 3.21(2) $\AA$ ] to form 1-D chains (Fig. 4a). A further set of $\mathrm{C}-\mathrm{H} \cdots \mathrm{S}$ interactions (depicted as red dashed lines in Fig. $4 \mathrm{~b}$; $\mathrm{C}-\mathrm{H} \cdots \mathrm{S}$ distances are 3.14 and $3.01 \AA$ A) connects adjacent 1-D chains to form a more complex arrangement, labelled as A.

The resulting crystal packing could be easily described as an assembly of 1-D chains of type A along the remaining two dimensions. In particular, adjacent 1-D molecular arrangements A are assembled along the [001] direction via $\mathrm{C}_{43}-\mathrm{H} \cdots \mathrm{S}$ interactions $\left(\mathrm{C}_{43}-\mathrm{H} \cdots \mathrm{S}\right.$ distance is $\left.3.09 \AA\right)$ assisted by a set of weaker $\mathrm{C}_{(\mathrm{Me})}-\mathrm{H} \cdots \mathrm{I}$ interactions $(\mathrm{C}-\mathrm{H} \cdots \mathrm{I}$ distances are $3.30,3.32$, and $3.29 \AA$ ) and related by $n$-glide planes parallel to the (101) plane which generates a change in their direction of propagation from [110] to [110] (respectively, orange and blue in Fig. 5a and b). The chains propagate along the [010] direction under the effect of $2_{1}$ screw axes, resulting in a herringbone motif (Fig. 5c).

In order to keep the comparative approach undertaken at the molecular level in the previous section, we have also extended the crystal packing analysis to the three crystal

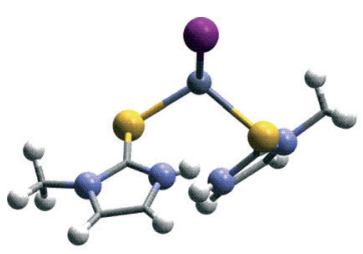

a)

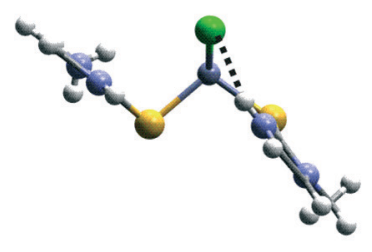

c)

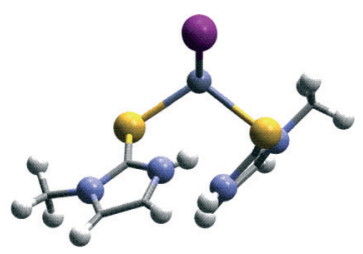

b)

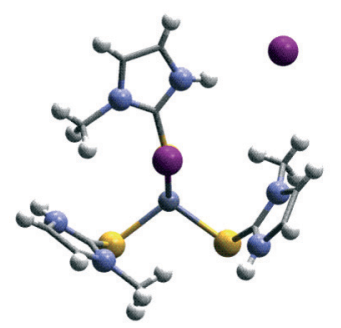

d)
Fig. 3 Conformational comparison of a) independent molecule 1, b) independent molecule 2, c) complex [ $\left.\mathrm{Zn}(\mathrm{MelmSH})_{2} \mathrm{Cl}_{2}\right]$, and d) complex $\left[\mathrm{Zn}(\mathrm{MelmSH})_{3}\right] \mathrm{I}$. The molecules are viewed along the direction parallel to the plane $X 1-Z n-X 2$ for a), b), and c) and viewed along the direction parallel to the plane $\mathrm{X} 1-\mathrm{Zn}-\mathrm{S} 3$ for $\mathrm{d}$ ). This results in the superimposition of the two halogens for $\mathrm{a}), \mathrm{b})$, and c) and of I and $S$ atoms in $d$ ). 


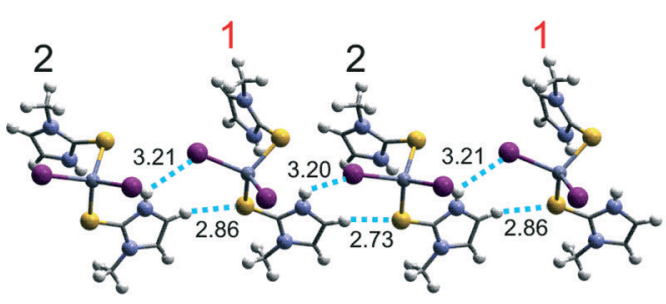

a)

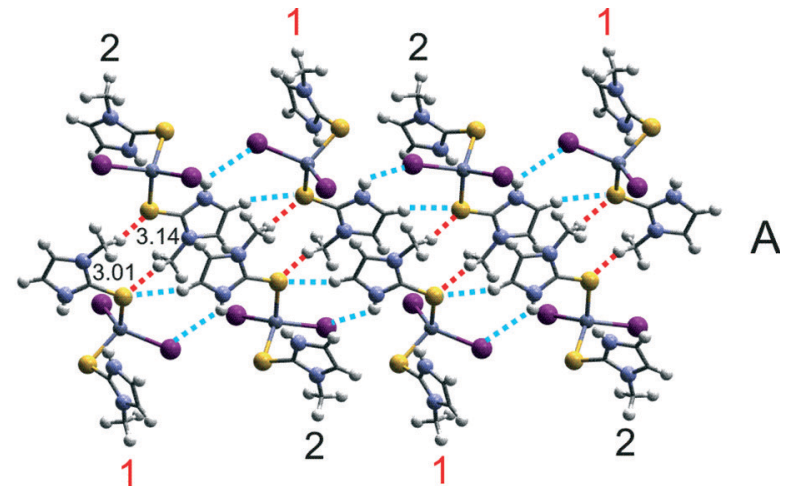

b)

Fig. 4 Representation of the main molecular arrangements identified for the structure of the complex $\left[\mathrm{Zn}(\mathrm{Me} / \mathrm{mSH})_{2} \mathrm{I}_{2}\right]$. a) Single 1-D chain, built by intermolecular interactions involving the two independent molecules 1 and 2; b) molecular arrangement A. The molecular arrangements are oriented to better show the intermolecular interactions. Bond distances are in $\AA$.
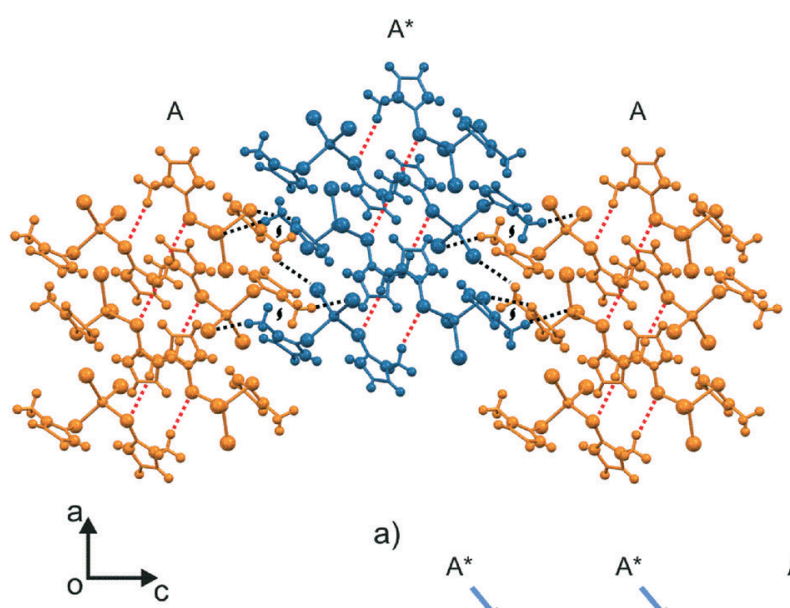

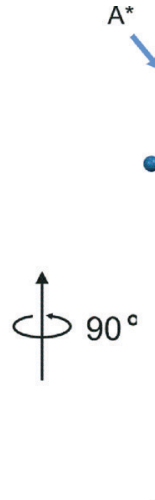

a)

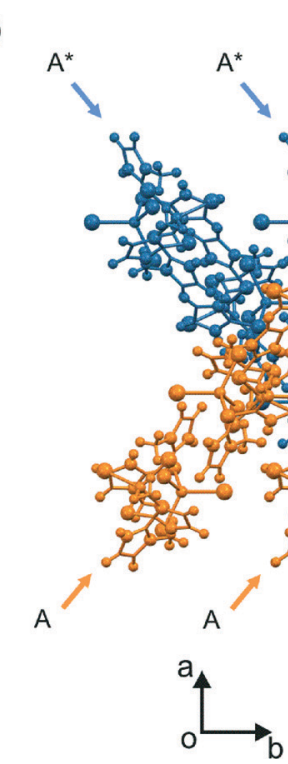

$A^{*}$

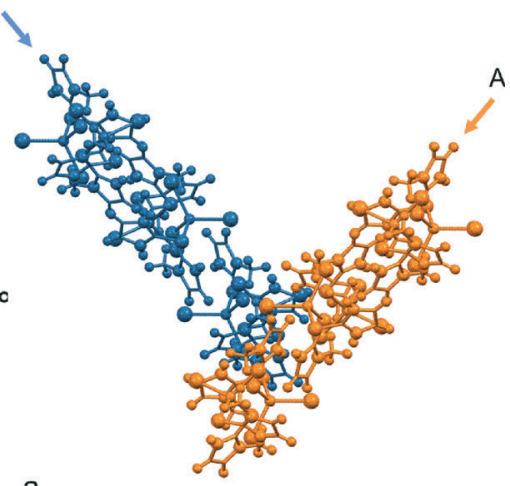

b)

Fig. 5 Representation of the crystal packing of the complex $\left[\mathrm{Zn}(\mathrm{MelmSH})_{2} \mathrm{l}_{2}\right]$. a) Crystal packing viewed along the [010] direction $\left(2_{1}\right.$ screw axes are indicated in black). Intermolecular interactions connecting adjacent chains are indicated by black dashed lines. Red colour is used for interactions within the molecular arrangements $A ; b$ ) development of the 1-D chains $A$ along the [001] direction under the effect of $n$-glide symmetry; c) crystal packing viewed along the [001] direction. The molecules are colour coded depending on the direction of propagation of the 1D chains: orange as the [110] direction, blue as the [110] direction. The differences in the orientation of the chains are also indicated by using different labels $\left(A\right.$ and $\left.A^{*}\right)$ and coloured arrows. 
structures $\quad\left[\mathrm{Zn}(\mathrm{MeImSH})_{2} \mathrm{Cl}_{2}\right], \quad\left[\mathrm{Zn}(\mathrm{MeImSH})_{2} \mathrm{Br}_{2}\right], \quad$ and $\left[\mathrm{Zn}(\mathrm{MeImSH})_{3} \mathrm{I}\right] \mathrm{I}$. The comparison of this set of closely related compounds is intended to assess the importance of various factors, such as intermolecular interaction, shape and conformation, in the resulting crystal packing. In particular, we adopt a retro-synthetic approach, aiming to identify recurring structural motifs (e.g. specific intermolecular interactions and/or specific molecular arrangements) that might have a role in determining crystal packing similarities and/or differences. ${ }^{11}$ Selected intermolecular and intramolecular distances are summarized in Table 4.

With the exception of the isostructural neutral complexes, a preliminary comparison of the unit cell parameters shows major differences. This is not surprising that the different conformations (Fig. 3) and, most importantly, the different number of independent molecules in the asymmetric unit $\left(Z^{\prime}\right)$ are taken into account. However, the analysis reveals some analogies, mainly concerning the common tendency to form specific intermolecular interactions. Similar to the observations for the complex $\left[\mathrm{Zn}(\mathrm{MeImSH})_{2} \mathrm{I}_{2}\right]$ (Fig. 4a), for all of the structures, it is possible to identify 1-D chains built via weak interactions of $\mathrm{C}_{(4)}-\mathrm{H} \cdots \mathrm{S}$ (Fig. 6a-d) involving $\mathrm{C}-\mathrm{H}$ adjacent to the MeImSH N-H group $(\mathrm{C}-\mathrm{H} \cdots \mathrm{S}$ distances lie in the range 2.8-3.2 $\AA$ ). Furthermore, for the $\mathrm{Br}$ and $\mathrm{Cl}$ complexes
(Fig. $6 \mathrm{~b}$ and c), these are assisted by $\mathrm{N}-\mathrm{H} \cdots$ halogen contacts $(\mathrm{N}-\mathrm{H} \cdots \mathrm{Cl}$ and $\mathrm{N}-\mathrm{H} \cdots \mathrm{Br}$ distances are $2.55 \AA$ and $2.69 \AA)$, in a similar manner as observed for complex $\left[\mathrm{Zn}(\mathrm{MeImSH})_{2} \mathbf{I}_{2}\right]$. In the case of the ionic complex $\left[\mathrm{Zn}(\mathrm{MeImSH})_{3} \mathrm{I}\right] \mathrm{I}$, the $\mathrm{N}-\mathrm{H} \cdots$ halogen interaction is replaced by a set of $\mathrm{C}_{(\mathrm{Me})}-\mathrm{H} \cdots \mathrm{S}$ interactions $\left(\mathrm{C}_{(\mathrm{Me})}-\mathrm{H} \cdots \mathrm{S}\right.$ distances are 3.17 and $\left.3.20 \AA\right)$. The result is a set of $1 \mathrm{D}$ chains developing along the [010] direction for the isostructural set $\left[\mathrm{Zn}(\mathrm{MeImSH})_{2} \mathrm{Cl}_{2}\right]$ and $\left[\mathrm{Zn}(\mathrm{MeImSH})_{2} \mathrm{Br}_{2}\right]$ and along the $[110]$ direction for $\left[\mathrm{Zn}(\mathrm{MeImSH})_{3} \mathrm{I}\right] \mathrm{I}$.

These chains only differ from a geometrical point of view, arising from the different shape of the tetrahedral units. In fact, the different orientations of the MeImSH moieties in the three types of structures (Fig. 3) expose the $\mathrm{NH}$ and $\mathrm{CH}$ hydrogen bond donors along different directions generating differences in the resulting patterns. This is represented in Fig. 6, in which $\mathrm{C}-\mathrm{H} \cdots \mathrm{S}$ and $\mathrm{N}-\mathrm{H} \cdots$ halogen distances are also included.

Again, as already seen for the complex $\left[\mathrm{Zn}(\mathrm{MeImSH})_{2} \mathrm{I}_{2}\right]$ (Fig. 5), the crystal packing of the structures $\left[\mathrm{Zn}(\mathrm{MeImSH})_{2} \mathrm{Cl}_{2}\right]$, $\left[\mathrm{Zn}(\mathrm{MeImSH})_{2} \mathrm{Br}_{2}\right]$, and $\left[\mathrm{Zn}(\mathrm{MeImSH})_{3} \mathrm{I}\right] \mathrm{I}$ can be rationalised starting from these 1-D chains. In the isostructural complexes $\left[\mathrm{Zn}(\mathrm{MeImSH})_{2} \mathrm{Cl}_{2}\right]$ and $\left[\mathrm{Zn}(\mathrm{MeImSH})_{2} \mathrm{Br}_{2}\right]$, the 1-D chains are assembled via $2_{1}$ screw axes (Fig. 7) along the [100] direction via weak $\mathrm{C}_{(\mathrm{Me})}-\mathrm{H} \cdots \mathrm{S}(\mathrm{C}-\mathrm{H} \cdots \mathrm{S}$ distances are $2.94 \AA$ for the $\mathrm{Cl}$ derivative and $3.20 \AA$ for the $\mathrm{Br}$ derivative), and $\mathrm{C}_{(4)}-\mathrm{H} \cdots \mathrm{Hal}$

Table 4 Selected intermolecular and intramolecular distances $(\AA ̊)$ and angles $\left(^{\circ}\right)$ for the complexes $\left[\mathrm{Zn}\left(\mathrm{MelmSH}_{2} \mathrm{Br}_{2}\right](\mathrm{ref} .8),\left[\mathrm{Zn}\left(\mathrm{MelmSH}_{2} \mathrm{Cl}{ }_{2}\right](\mathrm{ref} .8)\right.\right.$, and $\left[\mathrm{Zn}(\mathrm{MelmSH})_{3}\right.$ ] I (ref. 8)

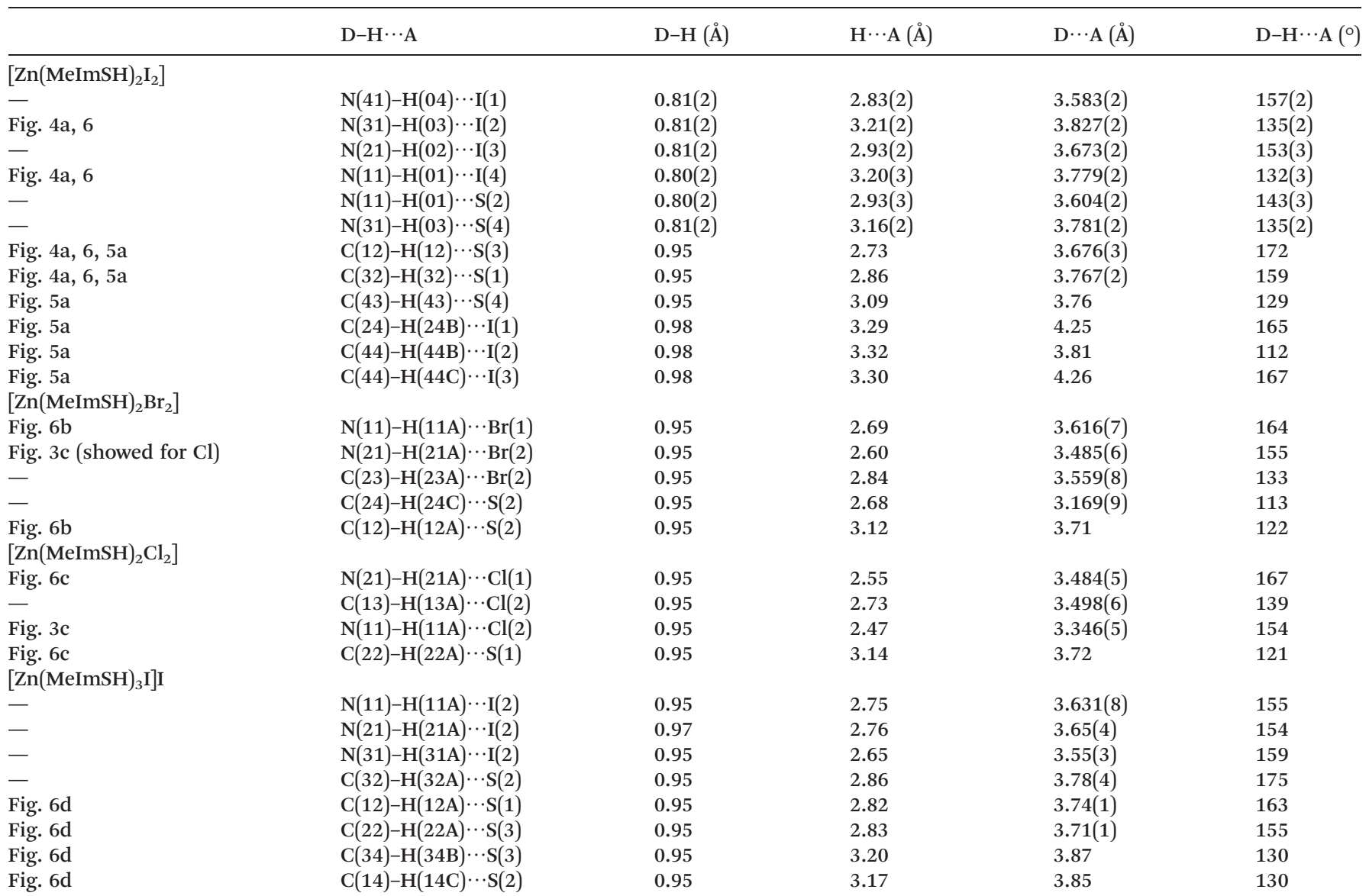




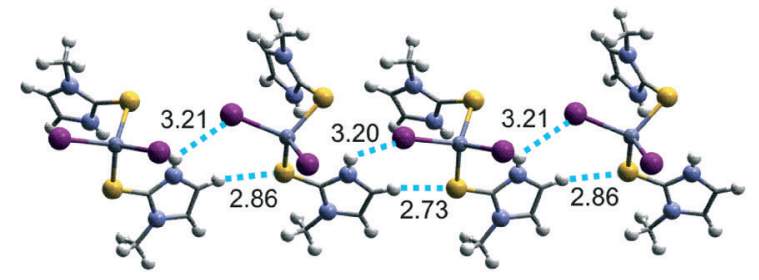

a)

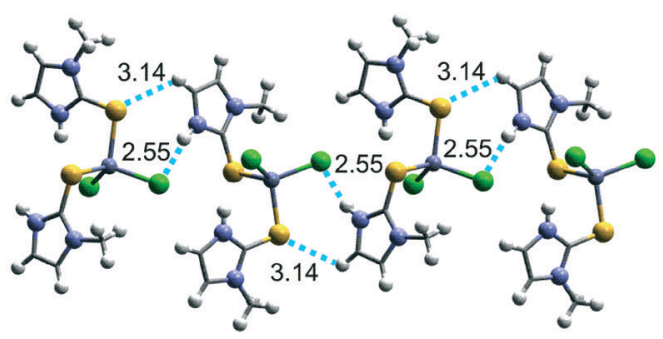

c)

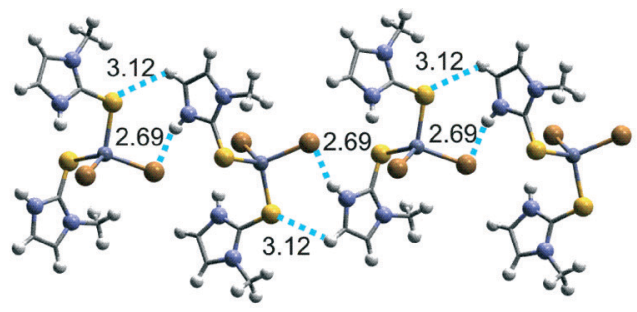

b)

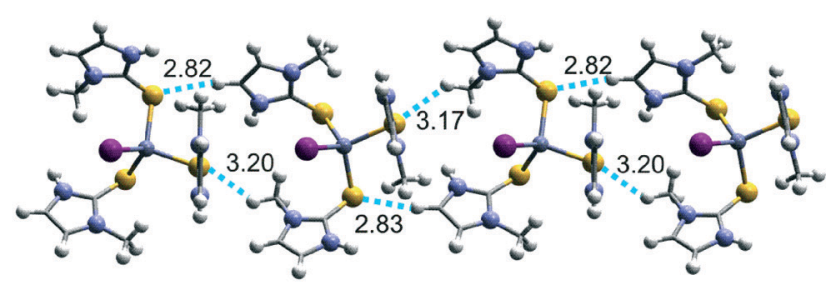

d)

Fig. 6 Representation of the main molecular arrangements identified for the structure of the complexes: a) $\left[\mathrm{Zn}(\mathrm{MelmSH})_{2} \mathrm{I}_{2}\right], \mathrm{C}-\mathrm{H} \cdots \mathrm{S}$ and $\mathrm{N}-\mathrm{H} \cdots \mathrm{I}$; b) $\left[\mathrm{Zn}(\mathrm{MelmSH})_{2} \mathrm{Br}_{2}\right], \mathrm{C}-\mathrm{H} \cdots \mathrm{S}$ and $\mathrm{N}-\mathrm{H} \cdots \mathrm{Br}$; c) $\left[\mathrm{Zn}(\mathrm{MelmSH})_{2} \mathrm{Cl}_{2}\right], \mathrm{C}-\mathrm{H} \cdots \mathrm{S}$ and $\mathrm{N}-\mathrm{H} \cdots \mathrm{Cl}$; d) $\left[\mathrm{Zn}(\mathrm{MelmSH})_{3}\right]^{+}, \mathrm{C}(\mathrm{Me})-\mathrm{H} \cdots \mathrm{S}$ and $\mathrm{C}(4)-\mathrm{H} \cdots \mathrm{S}$. The interactions are depicted in blue, bond distances are in $\AA$.

interactions (intermolecular distances $2.73 \AA$ for the $\mathrm{Cl}$ derivative and $2.94 \AA$ for the $\mathrm{Br}$ derivative). The chains develop along the [001] direction by simple translation, with no intermolecular interactions occurring between adjacent chains. A similar behaviour is observed in $\left[\mathrm{Zn}(\mathrm{MeImSH})_{3} \mathrm{I}\right] \mathrm{I}$, where the different instances of the 1-D chains develop along the [001] direction via $2_{1}$ screw axes. Also in this case (Fig. 8), the adjacent chains are connected to each other via $\mathrm{C}_{(\mathrm{Me})}-\mathrm{H} \cdots \mathrm{S}$ interactions (C-H $\cdots \mathrm{S}$ intermolecular distance is $3.06 \AA)$.

As described above, the structural behaviour of closely related compounds has certainly highlighted major differences in their structures, but has also identified some similarities. In particular, the common tendency to interact via $\mathrm{C}-\mathrm{H} \cdots \mathrm{S}$ and $\mathrm{N}-\mathrm{H} \cdots \mathrm{X}(\mathrm{X}=\mathrm{Cl}, \mathrm{Br}$ and $\mathrm{I})$ interactions results in slightly different molecular arrangements. This fact indicates the important role of specific directional intermolecular interactions in directing packing modes.

The structural analysis clearly shows some features that deserve to be commented. First of all, as previously mentioned, the $\left[\mathrm{Zn}(\mathrm{MeImSH})_{2} \mathrm{I}_{2}\right]$ complex crystallises in the monoclinic crystal system (space group $P 2_{1} / c, Z^{\prime}=2$ ) while the isostructures $\left[\mathrm{Zn}(\mathrm{MeImSH})_{2} \mathrm{Cl}_{2}\right]$ and $\left[\mathrm{Zn}(\mathrm{MeImSH})_{2} \mathrm{Br}_{2}\right]$ are orthorhombic (space group $P 2_{1} 2_{1} 2_{1}, Z^{\prime}=1$ ). Such differences are not uncommon and could arise from the different conditions of crystallization. ${ }^{8}$ It is known that the nature of the solvent can play an important role during the nucleation processes and, consequently, in the resulting crystal structure. Depending on the reaction conditions, the same compound can crystallise with different crystal packing modes (as polymorphs or different solvates). In this specific case, the most relevant departure consists of a different number of independent molecules in the asymmetric unit $\left(Z^{\prime}=2\right.$ for $\left[\mathrm{Zn}(\mathrm{MeImSH})_{2} \mathrm{I}_{2}\right]$ and $Z^{\prime}=1$ for the isostructural set $\left[\mathrm{Zn}(\mathrm{MeImSH})_{2} \mathrm{Cl}_{2}\right]$ and $\left.\left[\mathrm{Zn}(\mathrm{MeImSH})_{2} \mathrm{Br}_{2}\right]\right)$. Crystal structures with $Z^{\prime}>1$ are quite common; among others, Anderson et al..$^{12}$ point out that, although many factors may contribute to the crystallization of molecule with $Z^{\prime}>1$, there is no general rule to explain this phenomenon. In this case, the absence of any specific intramolecular interaction in the $\left[\mathrm{Zn}(\mathrm{MeImSH})_{2} \mathrm{I}_{2}\right]$ complex, which generally might favour some specific conformations ${ }^{13}$ could determine a certain degree of conformational flexibility in solution. Desiraju ${ }^{14}$ defined a crystal with $Z^{\prime}>1$ as a "kinetic form which has been trapped before the molecules have adjusted themselves in their final orientations". Certainly, the condition of crystallization can have an important role in this context.

\section{Reactivity of MeImSH with $\mathrm{Zn}$ powder}

The reaction in $\mathrm{CH}_{2} \mathrm{Cl}_{2}$ between MeImSH and $\mathrm{Zn}$ powder (4:1 molar ratio) leads to the complete dissolution/oxidation of $\mathrm{Zn}$ in about 7 days. In the course of the reaction, a whitish solid powder precipitated. The electrospray ionization mass spectrum (ESI-MS), recorded in the positive ion mode, showed for this compound the highest peak at $m / z=405(100 \%)$ with an isotopic pattern consistent with the zinc-containing species $\mathrm{Zn}(\mathrm{MeImSH})(\mathrm{MeImS})_{2}+\mathrm{H}^{+}$(see the ESI $\dagger$ ). Unfortunately, because of its low solubility in common organic solvents and in water, it was not possible to carry out any study in solution nor to isolate suitable crystals for X-ray determination; in these circumstances MAS ${ }^{13} \mathrm{C}-\mathrm{NMR}$ spectroscopy proved to be a useful tool. In Table 5, the ${ }^{13} \mathrm{C}$ NMR data of MeImSH, complexes $\left[\mathrm{Zn}(\mathrm{MeImSH})_{2} \mathrm{I}_{2}\right]$ and $\left[\mathrm{Zn}(\mathrm{MeImSH})(\mathrm{MeImS})_{2}\right]$ are listed. As a consequence of S-coordination to the zinc(II) centre, effects on chemical shifts were found for all carbon 


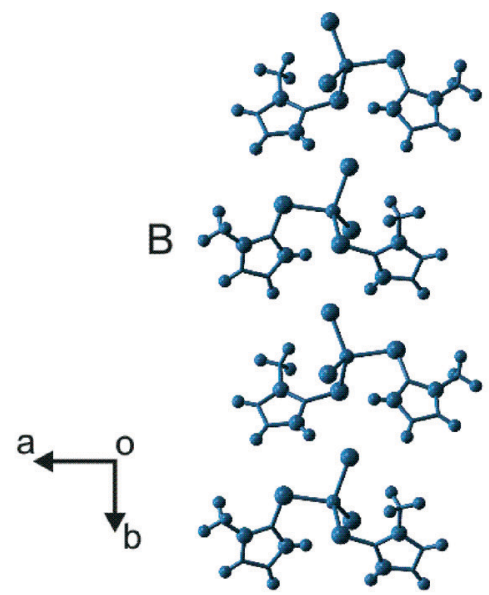

a)

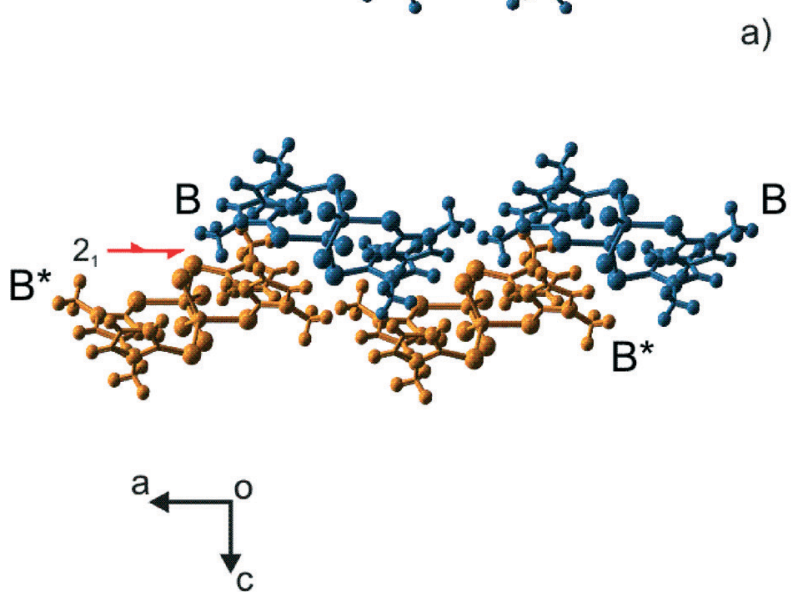

b)
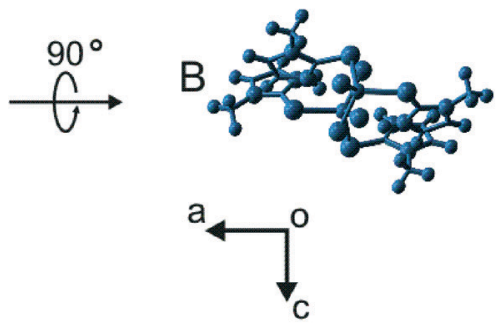

Fig. 7 Representation of the crystal packing of the isostructural set $\left[\mathrm{Zn}(\mathrm{MelmSH})_{2} \mathrm{Cl}_{2}\right]$ and $\left[\mathrm{Zn}(\mathrm{MelmSH})_{2} \mathrm{Br}_{2}\right]$ showed for the $\mathrm{Cl}$ derivative as representative. a) 1-D chain $B$ viewed along the 001 direction (left) and 1-D chain B viewed along the [010] direction (right); b) development of the crystal packing along the [100] direction. The 1-D chains B are assembled under the effect of $2_{1}$ screw axis (red arrows) and viewed along the [010] direction; c) 3-D packing viewed along the [010] direction. Instances of the 1-D chains B are colour coded according to the different orientations of propagation. The differences in the orientation of the chains are also indicated by using different labels ( $B$ and $B *)$.

nuclei. In complex $\left[\mathrm{Zn}(\mathrm{MeImSH})_{2} \mathrm{I}_{2}\right]$, the thioamido carbon proves to be most sensitive to complexation as confirmed by the markedly upfield shift ( $\approx 10 \mathrm{ppm})$; this is associated with the increased double bond character at the $\mathrm{C}(\mathrm{S})-\mathrm{N}$ linkage. Conversely, carbons C(4), and C(5) (see Fig. 1 for atom numbering) are slightly deshielded compared to free methimazole. The MAS spectrum of complex [ $\left.\mathrm{Zn}(\mathrm{MeImSH})(\mathrm{MeImS})_{2}\right]$ shows interesting features since both the resonances related to methimazole in its neutral and anionic forms are observed. The resonance of thioamido carbon in MeIms is further shifted upfield with respect to that of the MeImSH moiety, since $\mathrm{NH}$ deprotonation causes an increase in the $\pi$-electron density delocalisation involving the carbon and the nitrogen atoms of the thioamide group. The experimental data suggest that oxidation/complexation of elemental zinc by MeImSH proceeds in accordance with the overall process:

$$
3 \mathrm{MeImSH}+\mathrm{Zn} \rightarrow \mathrm{Zn}(\mathrm{MeImSH})(\mathrm{MeImS})_{2}+\mathrm{H}_{2}
$$

The reaction (3) is in accordance with the results reported by Sousa $e t ~ a l .{ }^{15}$ about the electrochemical oxidation of a zinc

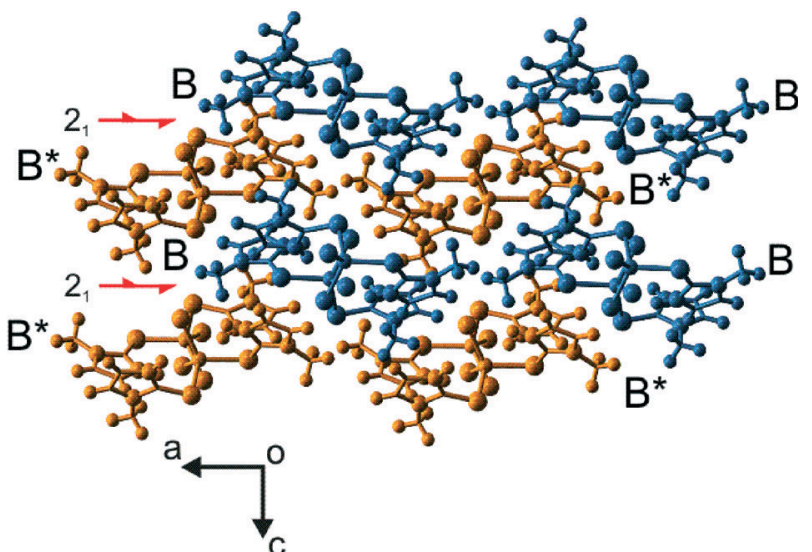

C) anode in a solution of MeImSH in acetonitrile. Moreover, Sousa reported on the crystal structure of complex $\left[\mathrm{Zn}_{4} \mathrm{O}(\mathrm{MeImS})_{6}\right]$ that features MeImS acting as a $(\mathrm{N}, \mathrm{S})$-bridging ligand that binds pairs of non-interacting zinc atoms. ${ }^{15}$

\section{Reactivity of complex [Zn(MeImSH)(MeImS $\left.)_{2}\right]$ with HI}

Complex $\left[\mathrm{Zn}(\mathrm{MeImSH})(\mathrm{MeImS})_{2}\right]$ shows a low solubility in the most common organic solvents and in water; however, it is readily solubilized in hydroiodic acid (HI) solutions. The reaction of $\left[\mathrm{Zn}(\mathrm{MeImSH})(\mathrm{MeImS})_{2}\right]$, suspended in a mixture of $\mathrm{CH}_{3} \mathrm{CN}-\mathrm{CH}_{2} \mathrm{Cl}_{2}$ with a ratio of $1: 1(\mathrm{v} / \mathrm{v})$, and $\mathrm{HI}(57 \mathrm{wt} . \%$ in water) (molar ratio of the $\mathrm{Zn}$ complex to $\mathrm{HI}$ is $1: 2$ ) readily causes the dissolution of the suspended powder with formation of a clear solution. By slow evaporation of the solvents, a pale yellow powder was obtained; the compound was identified by elemental analysis and IR spectroscopy as the complex $\left[\mathrm{Zn}(\mathrm{MeImSH})_{3} \mathrm{I}\right] \mathrm{I}$ isolated by Fujisawa ${ }^{8}$ (Scheme 2 ). We also verified that the protonation process was reversible; indeed, the addition to $\left[\mathrm{Zn}(\mathrm{MeImSH})_{3} \mathrm{I}\right] \mathrm{I}$ of three equivalents of the strong organic base 1,8-bis(dimethylamino)naphthalene (DMAN) in a 


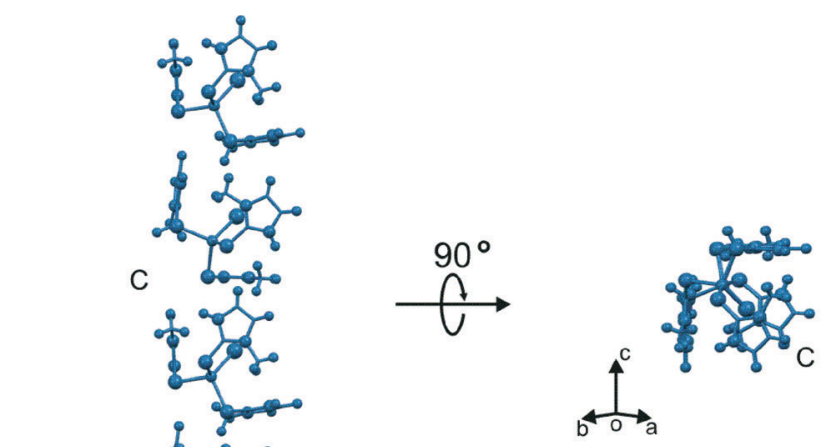

a)

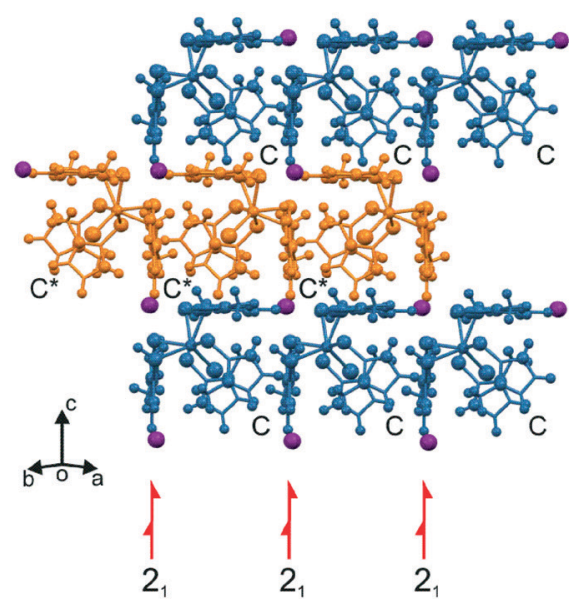

c)

Fig. 8 Representation of the crystal packing of the complex [ $\left.\mathrm{Zn}(\mathrm{MelmSH})_{3} \mathrm{I}\right] \mathrm{I}$. a) 1-D chain C viewed along the [010] direction (left) and 1-D chain

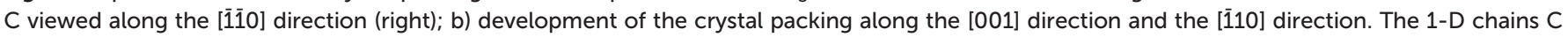
are assembled via the 2 screw axis (red arrows) operating along the [001] direction and by simple translation along the [110] direction. The portion

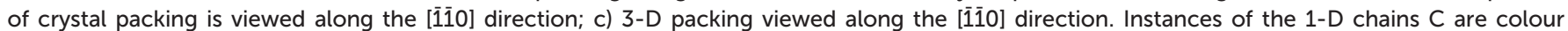
coded according to the different orientations of propagation. The differences in the orientation of the chains are also indicated by using different labels ( $\mathrm{C}$ and $\mathrm{C} *$ ).

Table $5{ }^{13} \mathrm{C}$ NMR spectral data of MelmSH and its related zinc complexes $\left[\delta\right.$ in ppm, $\left.25^{\circ} \mathrm{C}\right]$

\begin{tabular}{llllll}
\hline Compound & $\mathrm{C}=\mathrm{S}$ & $\mathrm{C} 5$ & $\mathrm{C} 4$ & $\mathrm{~N}^{-\mathrm{CH}_{3}}$ & Solvent \\
\hline MeImSH & 163.3 & 120.0 & 114.2 & 34.0 & $\mathrm{CDCl}_{3}-\mathrm{CH}_{3} \mathrm{CN}_{(4: 1(\mathrm{v}: \mathrm{v}))}$ \\
{$\left[\mathrm{Zn}(\mathrm{MeImSH})_{2} \mathrm{I}_{2}\right]$} & 152.5 & 120.6 & 115.4 & 34.1 & $\mathrm{CDCl}_{3}-\mathrm{CH}_{3} \mathrm{CN}_{(4: 1(\mathrm{v}: \mathrm{v}))}$ \\
{$\left[\mathrm{Zn}(\mathrm{MeImSH})(\mathrm{MeImS})_{2}\right]$} & 150.8 & 122.6 & 117.9 & 32.5 & Solid state \\
& 146.7 & 120.3 & 113.6 & 30.5 &
\end{tabular}

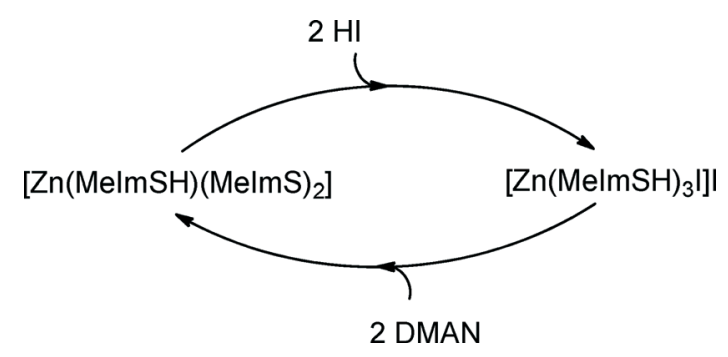

Scheme 2 Deprotonation/protonation assisted conversion of $\mathrm{Zn}$-coordinated methimazole from thionato to thione forms. mixture of $\mathrm{CH}_{3} \mathrm{CN}-\mathrm{CH}_{2} \mathrm{Cl}_{2}$ with a ratio of $1: 1(\mathrm{v} / \mathrm{v})$, resulted in the formation of a whitish powder identified as the expected complex $\left[\mathrm{Zn}(\mathrm{MeImSH})(\mathrm{MeImS})_{2}\right]$ (Scheme 2). The deprotonation/protonation of the coordinated methimazole units can modulate the coordination environment at the $\mathrm{Zn}$-core; as a consequence of methimazole NH-deprotonation, the binding mode changes from S-monodentate to an N,S-bridging mode.

\section{Conclusions}

The oxidative dissolution of zinc powder by either the $I_{2}$ adduct of antithyroid drug methimazole or methimazole alone is easily 
accomplished in $\mathrm{CH}_{2} \mathrm{Cl}_{2}$, leading to novel stable complexes of zinc(II), $\left[\mathrm{Zn}(\mathrm{MeImSH})_{2} \mathrm{I}_{2}\right]$ and $\left[\mathrm{Zn}(\mathrm{MeImSH})(\mathrm{MeImS})_{2}\right]$, respectively. The X-ray crystal structure of the former complex shows two independent zinc(II) ions, each coordinated by two neutral ligands (via the S-atoms) and two iodides in a distorted tetrahedral coordination geometry. The crystal packing highlights the formation of 1-D chains built via weak interactions of $\mathrm{C}(4)-\mathrm{H} \cdots \mathrm{S}$ and $\mathrm{N}-\mathrm{H} \cdots$ halogen. These interactions also lead to the formation of 1-D chains in complexes $\left[\mathrm{Zn}(\mathrm{MeImSH})_{2} \mathrm{X}_{2}\right]$ $(\mathrm{X}=\mathrm{Br}$, and $\mathrm{Cl})$, whereas in the ionic complex $\left[\mathrm{Zn}(\mathrm{MeImSH})_{3} \mathrm{I}\right] \mathrm{I}$, the 1-D chain formation is based on weak interactions of $\mathrm{C}(4)-\mathrm{H} \cdots \mathrm{S}$ and $\mathrm{N}-\mathrm{CH}_{3} \cdots \mathrm{S}$. The results reported in this study confirm the propensity of the drug methimazole to form both a strong $\mathrm{Zn}-\mathrm{S}$ bond, and to activate intermolecular interactions in relation to the other ligands completing the zinc(II) coordination sphere. The average $\mathrm{Zn}-\mathrm{S}$ bond distance $[2.3492(5) \AA]$ in complexes $\left[\mathrm{Zn}(\mathrm{MeImSH})_{2} \mathrm{X}_{2}\right](\mathrm{X}=\mathrm{I}, \mathrm{Br}$, and $\mathrm{Cl})$ is reasonably similar to the average $\mathrm{Zn}$-cysteine bond lengths $[2.32 \pm 0.16 \AA]$ found in zinc proteins determined by NMR, ${ }^{5 f}$ this fact supports the hypothesis that methimazole could block one or more cysteine/histidine binding sites and thereby affect the multifunctional role of the zinc in the proteins.

The characterization of complex $\left[\mathrm{Zn}(\mathrm{MeImSH})(\mathrm{MeImS})_{2}\right]$ shows neutral (thione) and anionic (thionate) methimazole units coordinating to the metal centre. Based on the reactivities of complexes $\left[\mathrm{Zn}(\mathrm{MeImSH})(\mathrm{MeImS})_{2}\right]$ and $\left[\mathrm{Zn}(\mathrm{MeImSH})_{3} \mathrm{I}\right] \mathrm{I}$, we have shown that the $\mathrm{NH}$ deprotonation of methimazole S-coordinated to the $\mathrm{Zn}$ (II) ion modifies the coordinating characteristics of this ligand from S-monodentate to N,S-bridging. In the latter case, the anionic methimazole could bind two $\mathrm{Zn}$ (II) centres in close proximity, as reported in the complex $\left[\mathrm{Zn}_{4} \mathrm{O}(\mathrm{MeImS})_{6}\right]$ where $d(\mathrm{Zn}-\mathrm{Zn}) \approx 3.2 \AA^{15}{ }^{15}$ Within the scope of the study of the interaction of molecules of biological/ pharmacological interest with zinc, the results underline that methimazole may in some ways be a dangerous metalcoordinating compound, connected with the formation of a stable zinc(II)-thioamide moiety and the formation of hydrogen bonds via $\mathrm{NH}, \mathrm{N}-\mathrm{CH}_{3}$, and $\mathrm{C}(4) \mathrm{H}$ groups. Moreover, the Zn-coordinated methimazole can markedly modify the coordination environment when changing from its thione to thionate form, and vice versa.

\section{Experimental}

\section{Materials and instrumentation}

Reagents were used as purchased from Aldrich. Elemental analyses were carried out using a Fisons Instruments 1108 CHNS elemental analyser. FT-Infrared spectra of powdered samples were measured using a Thermo-Nicolet 5700 spectrometer from $4000-400 \mathrm{~cm}^{-1}$ in the form of pressed $\mathrm{KBr}$ pellets. ${ }^{13} \mathrm{C}$ NMR spectra were recorded using a Varian $400 \mathrm{MHz}$ spectrometer, chemical shifts are reported in $\operatorname{ppm}(\delta)$ downfield from TMS using the same solvent as the internal reference; ${ }^{13} \mathrm{C}$ NMR MAS spectra were calibrated such that the observed up field peak in the spectrum of adamantane is set to $\delta=31.47$. All of the low resolution mass spectra were recorded by electrospray ionisation using a Fisons VG platform instrument or a Waters ZMD quadrupole mass spectrometer in HPLC grade acetonitrile.

\section{Synthesis of complex $\left[\mathrm{Zn}(\mathrm{MeImSH})_{2} \mathbf{I}_{2}\right]$}

A mixture of $\mathrm{MeImSH} \cdot \mathrm{I}_{2}(0.7874 \mathrm{~g}, 2.139 \mathrm{mmol}), \mathrm{MeImSH}$ $(0.2442 \mathrm{~g}, 2.139 \mathrm{mmol})$, and zinc dust $(<10 \mu \mathrm{m})(0.1398 \mathrm{~g}$, $2.139 \mathrm{mmol})$ in $\mathrm{CH}_{2} \mathrm{Cl}_{2}(50 \mathrm{~mL})$ was stirred at $25^{\circ} \mathrm{C}$ for 2 days. The resultant clear, pale yellow solution was slowly concentrated to dryness, and the white solid powder was washed with a $1: 1(\mathrm{v}: \mathrm{v}) \mathrm{CH}_{2} \mathrm{Cl}_{2}-n$-hexane mixture $(2 \times 5 \mathrm{~mL})$ and then dried in vacuo. Yield: $0.6440 \mathrm{~g}, 55.0 \%$ referring to zinc. Pale yellow single crystals for $\mathrm{X}$-ray analysis were obtained by dissolving the title compound in a $2: 1(\mathrm{v}: \mathrm{v})$ mixture of $\mathrm{CH}_{2} \mathrm{Cl}_{2}-$ $n$-hexane and cooling the solution at $5{ }^{\circ} \mathrm{C}$ for a few days. $\mathrm{C}_{8} \mathrm{H}_{12} \mathrm{I}_{2} \mathrm{~N}_{4} \mathrm{~S}_{2} \mathrm{Zn}$ (547.519): calcd. C 17.54, H 2.21, N 10.23, S 11.68; found: C 17.4, H 2.2, N 10.1, S 11.7. IR (KBr, $\left.v \mathrm{~cm}^{-1}\right)$ : $3287 \mathrm{br}, 3163 \mathrm{~m}, 3133 \mathrm{~m}, 1682 \mathrm{w}, 1572 \mathrm{~s}, 1468 \mathrm{~s}, 1450 \mathrm{~s}, 1404 \mathrm{~m}$, $1350 \mathrm{w}, 1280 \mathrm{~m}, 1155 \mathrm{~m}, 1086 \mathrm{~m}, 1015 \mathrm{w}, 920 \mathrm{w}, 839 \mathrm{w}, 733 \mathrm{~s}$, $685 \mathrm{~m}, 667 \mathrm{~s}, 627 \mathrm{~s}, 595 \mathrm{~m}, 510 \mathrm{~m}, 418 \mathrm{w}, 406 \mathrm{w}$.

\section{Synthesis of complex [ $\left.\mathrm{Zn}(\mathrm{MeImSH})(\mathrm{MeImS})_{2}\right]$}

A mixture of MeImSH (1.403 g, $12.294 \mathrm{mmol})$ and zinc dust $(<10 \mu \mathrm{m})(0.2610 \mathrm{~g}, 4.098 \mathrm{mmol})$ in $\mathrm{CH}_{2} \mathrm{Cl}_{2}(40 \mathrm{~mL})$ was sonicated for $5 \mathrm{~min}$, then stirred at $20^{\circ} \mathrm{C}$ for seven days. The whitish solid that precipitated in the course of the reaction was collected by suction filtration, washed with water and dried in vacuo. Yield $1.0740 \mathrm{~g}, 64.8 \%$ referring to zinc. $\mathrm{C}_{12} \mathrm{H}_{16} \mathrm{~N}_{6} \mathrm{~S}_{3} \mathrm{Zn}$ (405.89): calcd. C 35.51, H 3.98, N 20.72, S 23.66; found: C 35.8, H 4.0, N 20.8, S 23.7. IR (KBr, $v \mathrm{~cm}^{-1}$ ): 3105m, 2940w, $1457 \mathrm{vs}, 1369 \mathrm{vs}, 1314 \mathrm{vs}, 1285 \mathrm{vs}, 1144 \mathrm{vs}, 14001 \mathrm{~m}, 1368 \mathrm{~s}$, 1314s, 1245s, 1149s, 1084m, 1014w, 953w, 740s, 691s, 674s, 528w, 514w.

\section{X-ray structure determination of complex $\left[\mathrm{Zn}(\mathrm{MeImSH})_{2} \mathbf{I}_{2}\right]$}

A crystal ca. $0.25 \times 0.25 \times 0.13 \mathrm{~mm}$ was mounted in inert oil on a glass fibre and transferred to the cold gas stream of a Bruker SMART 1000 CCD diffractometer. Data were collected to $2 \theta_{\max }=61^{\circ}$ using monochromated Mo $\mathrm{K} \alpha$ radiation $(\lambda=0.71073 \AA)$. An absorption based on multi-scans was performed. The structure was refined anisotropically on $F^{2}$ using the program SHELXL-97. ${ }^{16} \mathrm{NH}$ hydrogens were refined freely but with $\mathrm{N}-\mathrm{H}$ distance restraints (SADI); methyls as idealized rigid groups were allowed to rotate but not tip; and other $\mathrm{H}$ atoms were refined using a riding model starting from calculated positions. Complete crystallographic data have been deposited at the Cambridge Crystallographic Data Centre, CCDC 976347.

\section{Acknowledgements}

We would like to thank Regione Autonoma della Sardegna for financial support. 


\section{Notes and references}

1 (a) V. Lippolis and F. Isaia, in Handbook of Chalcogen Chemistry: New Perspectives in Sulfur, Selenium and Tellurium, RSC Publishing, Cambridge, 2013, ch. 8.2, pp. 448-472; (b) W. T. Pennington, T. W. Hanks and H. D. Arman, in Halogen Bonding with Dihalogens and Interhalogens: Fundamentals and Applications, ed. P. Metrangolo and G. Resnati, SpingerVerlag, Berlin, 2008, pp. 65-104, and references therein.

2 (a) F. Isaia, M. C. Aragoni, M. Arca, C. Caltagirone, C. Castellano, F. Demartin, A. Garau, V. Lippolis and A. Pintus, Dalton Trans., 2011, 40, 4505-4513; (b) F. Isaia, M. C. Aragoni, M. Arca, C. Caltagirone, F. Demartin, A. Garau and V. Lippolis, Dalton Trans., 2013, 42(2), 492-498; (c) F. Bigoli, P. Deplano, F. A. Devillanova, V. Lippolis, M. L. Mercuri, M. A. Pellinghelli and E. F. Trogu, Inorg. Chim. Acta, 1998, 267, 115-121; (d) F. Bigoli, P. Deplano, M. L. Mercuri, M. A. Pellinghelli, G. Pintus, A. Serpe and E. F. Trogu, Chem. Commun., 1998, 2351-2352; (e) F. Bigoli, M. C. Cabras, P. Deplano, M. L. Mercuri, L. Marchiò, A. Serpe and E. F. Trogu, Eur. J. Inorg. Chem., 2004, 5, 960-963; $(f)$ A. Serpe, F. Bigoli, M. C. Cabras, P. Fornasiero, M. Graziani, M. L. Mercuri, T. Montini, L. Pilia, E. F. Trogu and P. Deplano, Chem. Commun., 2005, 1040-1042.

$3 K_{\mathrm{f}}$ values can spread over a very wide range of values depending on the nature of DS and solvent, i.e. 1:1 adduct methimazole- $\mathrm{I}_{2}, K_{\mathrm{f}}=92433 \mathrm{~L} \mathrm{~mol}^{-1}, \mathrm{CH}_{2} \mathrm{Cl}_{2}, 25^{\circ} \mathrm{C}, 1: 1$ adduct dimethyl sulfide- $\mathrm{I}_{2}, K_{\mathrm{f}}=74.0 \mathrm{~L} \mathrm{~mol}^{-1}, \mathrm{CCl}_{4}, 25{ }^{\circ} \mathrm{C}$. M. C. Aragoni, M. Arca, F. A. Devillanova, A. Garau, F. Isaia, V. Lippolis and G. Verani, Coord. Chem. Rev., 1999, 184, 271-290; and references therein.

4 (a) The drug methimazole, preventing iodine and thyroperoxidase enzyme from their normal interactions with thyroglobulin to form thyroid hormones thyroxine (T4) and triiodothyronine (T3), decreases thyroid hormone production. D. S. Cooper, N. Engl. J. Med., 2005, 352, 905-917; (b) C. Laurence, M. J. El Ghomari, J.-Y. Le Questel and R. Mokhlisse, J. Chem. Soc., Perkin Trans. 2, 1998, 1545-1551, and references therein; (c) H. N. Po and M. C. Keindl, J. Am. Chem. Soc., 1988, 110, 2586-2591; (d) F. Isaia, M. C. Aragoni, M. Arca, F. Demartin, F. A. Devillanova, G. Floris, A. Garau, M. B. Hursthouse, V. Lippolis, R. Medda, F. Oppo, M. Pira and G. Verani, J. Med. Chem., 2008, 51, 4050-4053.

5 (a) Toxicological profile for Zinc, Agency for Toxic Substances and Disease Registry (ATSDR), U.S. Department of Health and Human Services, Public Health Service, Atlanta, GA, 2005; (b) D. S. Auld, BioMetals, 2001, 14, 271-273; (c) S. Hughes and S. Saran, J. Am. Coll. Nutr., 2006, 25, 285-291; (d) D. Keilin and T. Mann, Nature, 1939, 144, 442-443; (e) W. Maret, Adv. Nutr., 2013, 4, 82-91; $(f)$ M. Laitaoja, J. Valjakka and J. Jänis, Inorg. Chem., 2013, 52, 10983-10991.

6 (a) A. A. Alturfan, E. Zengin, N. Dariyerli, E. E. Alturfan, M. K. Gumustas, E. Aytac, M. Aslan, N. Balkis, A. Aksu, G. Yigit, E. Uslu and E. Kokoglu, Folia Biol., 2007, 53, 183-188; (b) N. M. Urquiza, S. G. Manca, M. A. Moyano, R. A. Dellmans, L. Lezama, T. Rojo, L. G. Naso, P. A. M. Williams and E. G. Ferrer, BioMetals, 2010, 23, 255-264.

7 (a) E. S. Raper, Coord. Chem. Rev., 1997, 165, 475-567; (b) A. Rodríguez, J. A. García-Vázquez, A. Sousa-Pedrares, J. Romero and A. Sousa, Inorg. Chem. Commun., 2003, 6, 619-622; (c) A. Rodríguez, A. Sousa-Pedrares, J. A. García-Vázquez, J. Romero and A. Sousa, Eur. J. Inorg. Chem., 2005, 2242-2254; (d) A. Rodríguez, A. Sousa-Pedrares, J. A. García-Vázquez, J. Romero and A. Sousa, Eur. J. Inorg. Chem., 2007, 1444-1456.

8 Y. Matsunaga, K. Fujisawa, N. Amir, Y. Miyashita and K.-I. Okamoto, J. Coord. Chem., 2005, 58, 1047-1061.

9 No reaction is observed between zinc powder and iodine in $\mathrm{CH}_{2} \mathrm{Cl}_{2}$ at $25{ }^{\circ} \mathrm{C}$.

10 (a) R. H. Crabtree, in Oxidative Addition and Reductive Elimination The Organometallic Chemistry of the Transition Metals, Wiley-Interscience, Hoboken, USA, 4th edn, 2005, pp. 159-182; (b) J. Halpern, Acc. Chem. Res., 1970, 3, 386-392.

11 (a) R. Montis and M. B. Hursthouse, CrystEngComm, 2012, 14(21), 7466-7478; (b) M. B. Hursthouse, R. Montis, L. Niitsoo, J. Sarson, T. L. Threlfall, A. M. Asiri, S. A. Khan, A. Y. Obaid and L. M. Al-Harbi, CrystEngComm, 2014, 16, 2205-2219.

12 K. M. Anderson, S. E. Tallentire, M. R. Probert, A. S. E. Goeta, B. G. Mendis and J. W. Steed, Cryst. Growth Des., 2011, 11(3), 820-826.

13 M. Olivari, C. Caltagirone, A. Garau, F. Isaia, M. E. Light, V. Lippolis, R. Montis and M. A. Scorciapino, New J. Chem., 2013, 37(3), 663-669.

14 G. R. Desiraju, Angew. Chem., Int. Ed., 2007, 46(44), 8342-8356.

15 R. Castro, J. A. Garcia-Vasquez, J. Romero, A. Sousa, Y. D. Chang and J. Zubieta, Inorg. Chim. Acta, 1995, 237, 143-146.

16 G. M. Sheldrick, Acta Crystallogr., Sect. A: Found. Crystallogr., 2008, 64, 112-122. 